\title{
Okoliczności ekskulpujące odpowiedzialność za nieterminową lub w kwocie niższej od wymaganej zapłatę składek na ubezpieczenie społeczne
}

\section{The Circumstances which Exculpate Responsibility for Delayed or Lower than Required Payment of the Social Insurance Contributions}

Streszczenie. W opracowaniu omówiono naruszenie dyscypliny finansów publicznych z art. 14 pkt 1 ustawy z dnia 17 grudnia 2004 r. o odpowiedzialności za naruszenie dyscypliny finansów publicznych, tj. spoczywający na jednostkach sektora finansów publicznych obowiązek terminowego i w ustalonej ustawowo wysokości opłacania składek na ubezpieczenie społeczne, w szczególności zaś zakres podmiotowy i przedmiotowy ww. czynu. Autor omawia okoliczności ekskulpujące odpowiedzialność za czyn z art. 14 pkt 1 ww. ustawy i dokonuje analizy różnych stanów faktycznych, rozpoznawanych przez właściwe komisje orzekające oraz przez sądy administracyjne. Celem, jaki przyświeca niniejszemu opracowaniu, jest ukazanie złożoności analizowanego zagadnienia i różnorodno- 
ści czynników decydujących o ukaraniu lub o odstąpieniu od zarzutu popełnienia czynu z art. 14 pkt 1 ww. ustawy.

Słowa kluczowe: składki na ubezpieczenie społeczne; odpowiedzialność za naruszenie dyscypliny finansów publicznych.

\begin{abstract}
Author of the study attempts to show the area of protection of Polish public finances before the violations in discipline of the public finance in the area of social insurance contributions paid by the public sector unit. The analysis of subjective and objective scope of the act specified in Art. 14 of the Act of $17^{\text {th }}$ December 2004 on the liability for violation of public finance discipline, in line with the course of the discussion on the advisability of establishing obligations under that provision. The author analyzes the legal status on $24^{\text {th }}$ June 2014 , using not only the basic acts of financial law, but also referring to the doctrine and judicature, which refer factually to the subject of this study. Main aim of the study is to show the complexity of the issue that is analyzed and the diversities of factors that determine the punishment or the withdrawal objection of committing an act of Art. 14 point 1 of the above-mentioned the Act.
\end{abstract}

Keywords: social insurance contributions; liability for violation of public finance discipline.

\title{
1. Wstęp
}

Na jednostkach sektora finansów publicznych (dalej: j.s.f.p.) spoczywa obowiązek terminowego i w ustalonej ustawowo wysokości opłacania składek na ubezpieczenie społeczne. Zaniechanie ww. obowiązku może pociągać za sobą negatywne skutki w postaci wszczęcia postępowania w sprawie o czyn z art. 14 pkt 1 ustawy z dnia 17 grudnia 2004 r. o odpowiedzialności za naruszenie dyscypliny finansów publicznych ${ }^{1}$.

W konkretnych okolicznościach może mieć jednak miejsce wyłączenie odpowiedzialności, pomimo że czyn zawiniony, stanowiący naruszenie dyscypliny finansów publicznych, faktycznie został popełniony. Autor opracowania dokonuje analizy różnych stanów faktycznych, rozpoznawanych przez właściwe komisje orzekające w takich sprawach oraz przez

1 Tekst jedn. Dz.U. z 2013, poz. 168 (dalej: u.o.n.d.f.p). 
sądy administracyjne, które dotyczyły naruszenia art. 14 u.o.n.d.f.p., w szczególności zaś obowiązku opłacania składek na ubezpieczenie społeczne. Celem, jaki przyświeca niniejszemu opracowaniu, jest ukazanie złożoności analizowanego zagadnienia i różnorodności czynników decydujących o ukaraniu lub o odstąpieniu od zarzutu popełnienia czynu z art. 14 pkt 1 u.o.n.d.f.p.

W opracowaniu szczegółowo omówiono również zakres podmiotowy i przedmiotowy art. 14 pkt 1 u.o.n.d.f.p., uwzględniając dorobek orzeczniczy komisji orzekających w sprawach o naruszenie dyscypliny finansów publicznych, Głównej Komisji Orzekającej w Sprawach o Naruszenie Dyscypliny Finansów Publicznych (dalej: GKO), sądów oraz poglądy wyrażone w literaturze przedmiotu.

\section{Podstawy prawne poboru składek na ubezpieczenie społeczne i dochodzenia odpowiedzialności}

za naruszenie art. 14 u.o.n.d.f.p.

Zagwarantowane konstytucyjnie ${ }^{2}$ prawo obywatela do zabezpieczenia społecznego stanowi podstawę do uregulowania w akcie prawnym o randze ustawy zakresu i formy zabezpieczenia społecznego w razie niezdolności do pracy ze względu na chorobę lub inwalidztwo oraz po osiągnięciu wieku emerytalnego, a także dla pozostających bez pracy nie z własnej woli i niemających innych środków utrzymania. Upoważnienia zawarte w art. 67 Konstytucji RP są adresowane przede wszystkim do ustawodawcy i wiążą się z obowiązkiem podjęcia odpowiednich działań prawotwórczych w tym zakresie. Działania te zostały zmaterializowane i rozproszone w kilku ustawach m.in. w ustawie z dnia 13 października 1998 r. o systemie ubezpieczeń społecznych ${ }^{3}$, ustawie z dnia 17 grudnia 1998 r.

\footnotetext{
2 Art. 67 Konstytucji Rzeczypospolitej Polskiej z dnia 2 kwietnia 1997 r., Dz.U. Nr 78, poz. 483 ze zm.

$3 \quad$ Tekst jedn. Dz.U. 2013 r., poz. 1442 (dalej: u.s.u.s.).
} 
o emeryturach i rentach z Funduszu Ubezpieczeń Społecznych ${ }^{4}$, ustawie z dnia 25 czerwca 1999 r. o świadczeniach pieniężnych z ubezpieczenia społecznego $\mathrm{w}$ razie choroby i macierzyństwa ${ }^{5}$, czy też ustawie $\mathrm{z}$ dnia 30 października 2002 r. o ubezpieczeniu społecznym z tytułu wypadków przy pracy i chorób zawodowych ${ }^{6}$.

Przepisy art. 67 Konstytucji RP nie tworzą jednak bezpośrednio dla obywateli praw podmiotowych, na podstawie których mogliby oni występować z określonymi, konkretnymi żądaniami ${ }^{7}$, bowiem o powstaniu stosunku ubezpieczenia oraz formach i zakresie świadczeń decydują przepisy ustawy $^{8}$. Niemniej jednak koncepcja zabezpieczenia społecznego koresponduje z założeniami teorii opiekuńczości realizowanej przez państwo, według której obywatele otrzymują środki na zaspokojenie swoich potrzeb w trudnych dla nich okresach egzystencji (np. w okresach choroby, starości) z tytułu ciążącego na państwie jednostronnego i publicznoprawnego obowiązku udzielania ochrony socjalnej wszystkim ludziom w przypadkach losowych. Prawo ubezpieczeń społecznych jest zatem jednym z instrumentów polityki zabezpieczenia społecznego obywateli ${ }^{9}$, przy czym należy również wspomnieć, że pewne kwestie dotyczące ubezpieczeń społecznych mają swoje źródła w prawie międzynarodowym ${ }^{10}$.

Duże znaczenie w procesie realizowania ww. konstytucyjnej zasady mają środki pozyskane z uiszczanych - terminowo i w określonej usta-

Tekst jedn. Dz.U. 2013 r., poz. 1440.

Tekst jedn. Dz.U. 2014 r., poz. 159.

Tekst jedn. Dz.U. 2009 r., nr 167, poz. 1322 ze zm.

Por. wyrok NSA z dnia 17 stycznia 2006 r., I OSK 759/2005, CBOSA; wyrok SA w Warszawie z dnia 15 czerwca 2004 r., I ACa 1623/2003, LexPolonica nr 373175. Wyrok SN - Izba Administracyjna, Pracy i Ubezpieczeń Społecznych z dnia 20 stycznia 2000 r., II UKN 334/99, OSNAPiUS 2001, nr 11, poz. 393.

9 M. Cholewa-Klimek, Postępowanie sadowe w sprawach z zakresu ubezpieczeń społecznych, Warszawa 2010, s. 31-32.

10 Przykładowo: w Powszechnej Deklaracji Praw Człowieka uchwalonej przez Zgromadzenie Ogólne ONZ 10 grudnia 1948 r., w Konwencji o Ochronie Praw Człowieka i Podstawowych Wolności sporządzonej w Rzymie dnia 4 listopada 1950 r., wraz ze zmianami wprowadzonymi późniejszymi protokołami do ww. Konwencji; w Europejskiej Karcie Społecznej sporządzonej w Turynie dnia 18 października 1961 r. czy w konwencjach Międzynarodowej Organizacji Pracy ratyfikowanych przez Rzeczpospolitą Polską. Szerzej: G. Szyburska-Walczak, Ubezpieczenia Społeczne, Warszawa 2012, s. 30-31. 
wowo wysokości - składek na ubezpieczenie społeczne, dlatego tak istotne jest zachowanie dyscypliny w ich bieżącym regulowaniu. Analizując odpowiedzialność za naruszenie dyscypliny finansów publicznych, dodać należy, że w zakresie nieopłacania ww. składek przez j.s.f.p. albo ich opłacania w kwocie niższej niż wynikająca z prawidłowego obliczenia największe znaczenie mają uregulowania u.o.n.d.f.p., która stoi na straży zapewnienia szeroko pojętego ładu w finansach publicznych, również w zakresie przestrzegania prawa zabezpieczenia społecznego obywateli.

Zgodnie $\mathrm{z}$ art. 14 u.o.n.d.f.p. naruszeniem dyscypliny finansów publicznych jest nieopłacenie w terminie przez jednostkę sektora finansów publicznych składek na ubezpieczenie społeczne, składek na ubezpieczenie zdrowotne, składek na Fundusz Pracy, składek na Fundusz Gwarantowanych Świadczeń Pracowniczych, wpłat na Państwowy Fundusz Rehabilitacji Osób Niepełnosprawnych albo ich opłacenie w kwocie niższej niż wynikająca z prawidłowego obliczenia.

Analizując prawnomaterialne podstawy odpowiedzialności za czyn z art. 14 pkt 1 u.o.n.d.f.p., należy wskazać przede wszystkim na przepisy rozdziału 4 u.s.u.s., w szczególności art. 46 u.s.u.s., stanowiące o obowiązku płatnika składek opłacania, według zasad wynikających z przepisów u.s.u.s., należnej składki za każdy miesiąc kalendarzowy, a także na art. 47 ust. 1 u.s.u.s., zgodnie z którym płatnik składek przesyła w tym samym terminie deklarację rozliczeniową, imienne raporty miesięczne oraz opłaca składki za dany miesiąc nie później niż ${ }^{11}$ do 10 . dnia następnego miesiąca - dla osób fizycznych opłacających składkę wyłącznie za siebie; do 5. dnia następnego miesiąca - dla jednostek budżetowych i samorządowych zakładów budżetowych; do 15. dnia następnego miesiąca - dla pozostałych płatników ${ }^{12}$.

Prawnomaterialną podstawą odpowiedzialności za naruszenie ww. przepisu u.o.n.d.f.p. jest również art. 46 ust. 1 ustawy z dnia 27 sierpnia

11 Z zastrzeżeniem art. 47 ust. 1a, 2a i 2b u.s.u.s., które dotyczą w kolejności: twórców i artystów; płatników składek, którzy opłacają składki wyłącznie za siebie; osób prowadzących pozarolniczą działalność, opłacających składki wyłącznie za siebie lub osoby z nimi współpracujące.

12 Por. również: A. Dziedzic, Naruszenia z art. 14 i 15 ustawy, „Kontrola Finansowa” 2012, nr 9, s. 26. 
2009 r. o finansach publicznych ${ }^{13}$, zgodnie z którym wydatki z tytułu składek na ubezpieczenie społeczne i inne składki i opłaty obligatoryjne korzystają z prawa pierwszeństwa realizacji, tj. przed innymi wydatka$\mathrm{mi}^{14}$. Ludmiła Lipiec-Warzecha wskazuje, że: „Nieprawidłowości związane z obowiązkiem opłacania należności publicznoprawnych wynikają w szczególności z traktowania, przez niektórych dysponentów, środków, które powinny być odprowadzone z tytułu dokonywania wpłat należności publicznoprawnych, jako formy swoistego kredytowania działalności jednostki w razie jej przejściowych bądź stałych problemów z płynnością finansową"15. Dlatego też zasadne jest uznanie, iż szczególne obowiązki związane z uiszczaniem składek na ubezpieczenie społeczne sprowadzają się m.in. do tego, że składki te powinny być opłacane przy przyjęciu wysokiego stopnia ich priorytetu, a tym samym nie mogą być umieszczane na dalszym planie za ewentualnymi innymi zobowiązaniami. Godziłoby to bowiem w zasadę bezwzględnego pierwszeństwa terminowej realizacji zobowiązań ustawowych. W orzecznictwie $\mathrm{GKO}^{16}$ wyrażony został pogląd, że nawet dążenie do szeroko rozumianego „uzdrawiania finansów” j.s.f.p. nie może się to odbywać niezgodnie z obowiązującymi przepisami, tzn. kosztem realizacji obowiązku opłacania wymagalnych zobowiązań ustawowych, nieregulowania innych wymagalnych zobowiązań albo zaciągania zobowiązań z przekroczeniem zakresu upoważnienia.

13 Tekst jedn. Dz.U. 2013 r., poz. 885 ze zm. (dalej: u.f.p.).

14 Por.: Z. Ofiarski, Komentarz do art. 46 u.f.p., [w:] M. Karlikowska, W. Miemiec, Z. Ofiarski, K. Sawicka, Ustawa o finansach publicznych. Komentarz, Wrocław 2010 oraz L. Lipiec-Warzecha, Ustawa o finansach publicznych. Komentarz, Warszawa 2011, s. 235-236.

L. Lipiec-Warzecha, Odpowiedzialność za naruszenie dyscypliny finansów publicznych. Komentarz, Warszawa 2012, s. 169.

16 Orzeczenie GKO z dnia 14 stycznia 2013 r., BDF1/4900/118/126/11/3921, www.mf.gov.pl, dostęp: 24 czerwca 2014 r. oraz orzeczenie Regionalnej Komisji Orzekającej w Sprawach o Naruszenie Dyscypliny Finansów Publicznych przy Regionalnej izbie Obrachunkowej w Poznaniu z dnia 8 maja 2012 r., DB-0965/14/44/12, „Biuletyn Orzecznictwa w Sprawach o Naruszenie Dyscypliny Finansów Publicznych” 2012, nr 3, poz. 1 (dalej: „Biuletyn Orzecznictwa NFFP”). 


\section{Znamiona naruszenia}

\section{$\mathrm{z}$ art. 14 ust. 1 u.o.n.d.f.p.}

Naruszenie dyscypliny finansów publicznych, o którym mowa w art. 14 pkt 1 u.o.n.d.f.p., może być popełnione przez działanie lub zaniechanie, gdyż obejmuje ono zarówno zachowania polegające na opłaceniu składek na ubezpieczenie społeczne w kwocie niższej niż wynikająca z prawidłowego obliczenia $^{17}$, jak i nieopłacenie ww. składek w terminie ${ }^{18}$ określonym przez ustawodawcę w przepisach odrębnych, które regulują również zakres modyfikacji ustawowych terminów zapłaty należności. Przykładowo, w stanie faktycznym analizowanym w orzeczeniu GKO z 10 maja 2010 r. ${ }^{19}$ miało miejsce określenie - w drodze umowy z Zakładem Ubezpieczeń Społecznych - innych niż ustawowe terminów zapłaty składek, tj. przewidziano rozłożenie należności z tytułu nieopłaconych składek na raty, według określonego harmonogramu spłat zadłużenia. Warto również przytoczyć orzeczenie GKO z 29 marca 2012 r. $^{20}$, w którym wskazano, że przepis art. 14 pkt 1 u.o.n.d.f.p. nie uzależnia penalizacji ww. czynu od okresu opóźnień w zapłacie, gdyż deliktem jest wyłącznie nieterminowe przekazywanie składek na ubezpieczenie społeczne, które zakłócają szeroko rozumiany ład finansów publicznych. Z kolei w orzeczeniu z 1 czerwca

17 Prawidłowe obliczenie powinno wynikać z dokonania matematycznych działań uwzględniających zasady ustalania składek na ubezpieczenie społeczne, tj. przepisy art. 15-22 u.s.u.s.

18 Czas popełnienia czynu polegającego na nieopłaceniu składek na ubezpieczenie społeczne należy oceniać zgodnie $\mathrm{z}$ dyspozycją określoną $\mathrm{w}$ art. 21 u.o.n.d.f.p., tj. naruszenie dyscypliny finansów publicznych uważa się za popełnione w czasie, w którym sprawca działał lub zaniechał działania, do którego był obowiązany. Przy czym za czas popełnienia naruszenia dyscypliny finansów publicznych charakteryzującego się zaniechaniem należy przyjąć moment początkowy sytuacji, w której podmiot zobowiązany nie może już wykonać nałożonego na niego obowiązku, tj. dzień następujący po dniu, w którym można było dokonać powinnego, a zaniechanego przez sprawcę działania. Por. orzeczenie Resortowej Komisji Orzekającej z dnia 28 września 2009 r., RKO-75/2006, „Biuletyn Orzecznictwa NDFP” 2010, nr 1, poz. 2.

19 Orzeczenie GKO z dnia 10 maja 2010 r., BDF1/4900/30/36/10/768, LexPolonica nr 2539943.

20 Orzeczenie GKO z dnia 29 marca 2012 r., BDF1/4900/29/27/12/545, LexPolonica nr 3874738. 
2009 r. ${ }^{21}$ GKO uznała, że w razie jednodniowego opóźnienia w odprowadzaniu wpłat (choć te dotyczyły wpłat na PFRON, a nie składek na ubezpieczenie społeczne) i symbolicznej kwoty odsetek z tego tytułu, czyn wprawdzie zaistniał, ale jego szkodliwość dla finansów publicznych była znikoma, co uzasadniało umorzenie postępowania. Warto przy tym podkreślić, że czyny polegające na opłaceniu składek z przekroczeniem terminu zapłaty muszą być uważane za popełnione w momencie dokonania płatności ${ }^{22}$.

Dla zaistnienia naruszenia dyscypliny finansów publicznych określonego $\mathrm{w}$ art. 14 u.o.n.d.f.p. nie ma również znaczenia naliczenie i zapłata bądź nienaliczenie odsetek ${ }^{23}$, kar lub innych opłat ${ }^{24}$.

Katalog podmiotów, które mogą ponieść odpowiedzialność za naruszenie dyscypliny finansów publicznych z art. 14 pkt 1 u.o.n.d.f.p., określony został w art. 4 u.o.n.d.f.p. Czyn ten może być popełniony wyłącznie przez j.s.f.p. Wykluczone jest zatem popełnienie tego naruszenia przez inne podmioty, które są zobligowane do opłacania składek na ubezpieczenie społeczne, ale nie są zaliczane do j.s.f.p. (art. 9 u.f.p.) - np. przedsiębiorstwa czy spółki prawa handlowego. Z treści ww. przepisów wynika, że podmiotami mogącymi ponieść odpowiedzialność na podstawie art. 14 pkt 1 u.o.n.d.f.p. są: kierownik j.s.f.p. oraz pracownicy jednostek sektora finansów publicznych lub inne osoby, którym odrębną ustawą lub na jej podstawie powierzono wykonywanie obowiązków w takiej jednostce, których niewykonanie lub nienależyte wykonanie stanowi czyn naruszający dyscyplinę finansów publicznych.

21 Orzeczenie GKO z dnia 1 czerwca 2009 r., BDF1/4900/36/35/09/1192, „Biuletyn Orzecznictwa NDFP” 2009, nr 3, poz. 12.

22 Orzeczenie GKO z dnia 19 października 2009 r., BDF1/4900/51/51-RN-8/09/1822, „Biuletyn Orzecznictwa NDFP” 2009, nr 4, poz. 12 oraz por. E. Kowalczyk, Odpowiedzialność kierownika i głównego księgowego jednostki sektora finansów publicznych w zakresie rachunkowości i gospodarki finansowej, Gdańsk 2012, s. 51-52.

23 Orzeczenie GKO z dnia 26 lutego 2009 r., BDF1/4900/116/105/08/1605, LexPolonica nr 2443061 oraz szerzej: K. Borowska, Komentarz do art. 14 u.o.n.d.f.p., [w:] K. Borowska, A. Kościńska-Paszkowska, T. Bolek, Odpowiedzialność za naruszenie dyscypliny finansów publicznych. Komentarz, Warszawa 2012, s. 91-92.

Zob. cyt. orzeczenie GKO z dnia 14 stycznia 2013 r. 
Odnosząc się do pierwszego z ww. podmiotów, wskazać należy, że kierownik j.s.f.p. powinien się cechować wysoką świadomością prawną i na bieżąco analizować sytuację finansową kierowanej przez niego jednostki, a nadto gospodarować środkami finansowymi w taki sposób, aby wydatki były zsynchronizowane z dochodami, a zobowiązania - w tym obejmujące składki na ubezpieczenie społeczne - były regulowane terminowo $^{25}$. Praktyka orzecznicza w sprawach dotyczących naruszenia art. 14 u.o.n.d.f.p. wskazuje, że wiele naruszeń wynika z niezachowania przez kierownika j.s.f.p. odpowiednich reguł ostrożności w danych okolicznościach oraz standardów postępowania, które byłyby adekwatne do zajmowanego przez niego stanowiska ${ }^{26}$. Ze szczególnych wymogów staranności w prowadzeniu gospodarki finansowej j.s.f.p. i z zasady ogólnej sformułowanej w art. 53 ust. 1 u.f.p. wynika, że odpowiedzialność za naruszenie art. 14 u.o.n.d.f.p. ponosić może kierownik j.s.f.p., na którym spoczywa obowiązek prowadzenia gospodarki finansowej w sposób zgodny z obowiązującym porządkiem prawnym i respektujący ład finansów publicznych ${ }^{27}$.

Autor uznaje, że w całości słuszne jest ww. rozwiązanie piętnujące brak staranności kierownika j.s.f.p. w wykonywaniu obowiązków powiązanych z nieopłacaniem (opłacaniem w nienależytej wysokości) składek na ubezpieczenie społeczne. Kierownicy j.s.f.p. są zobowiązani do znajomości i przestrzegania przepisów z zakresu finansów publicznych w wyniku profesjonalnego charakteru wykonywanej przez nich działalności zawodowej $^{28}$. Dlatego kierownik j.s.f.p. powinien wykorzystywać wszyst-

\footnotetext{
Tamże.

26 Orzeczenie GKO z dnia 27 września 2010 r., BDF1/4900/72/79/10/2134, Lexis.pl nr 2540830.

27 Wyrok Wojewódzkiego Sądu Administracyjnego w Warszawie z dnia 14 maja 2012 r., VSA/Wa/216/12, „Biuletyn Orzecznictwa NDFP” 2012, nr 3, poz. 9.

28 Por. Orzeczenie Regionalnej Komisji Orzekającej w sprawach o naruszenie dyscypliny finansów publicznych przy Regionalnej Izbie Obrachunkowej w Lublinie z dnia 24 stycznia 2013 r., RIO-52/DFP-60/2012, [w:] M. Smaga, M. Winiarz, Dyscyplina finansów publicznych. Narzędzie prawidłowej gospodarki sektora publicznego, Kraków 2013, s. 521 oraz W. Bożek, Niewykonanie lub nienależyte wykonanie przez kierownika jednostki sektora finansów publicznych obowiqzków w zakresie kontroli zarzq̨dczej w jednostce sektora finansów publicznych, [w:] D. Zarzecki (red.), Zarzq̨dzanie Finansami. Zarzqdzanie finansami w przedsiębiorstwach i jednostkach samorzqdu teryto-
} 
kie przewidziane prawem instrumenty oddziaływania i dopiero, gdy one okażą się niewystarczające w danych okolicznościach, można ewentualnie rozważać brak zawinienia i w konsekwencji niedochodzenie odpowiedzialności za naruszenie art. 14 pkt 1 u.o.n.d.f.p. ${ }^{29}$

W rzeczywistości funkcjonowania j.s.f.p. zdarzają się sytuacje nadmiernego obdarzenia przez kierownika j.s.f.p. zaufaniem podległego mu pracownika (np. głównego księgowego) poprzez powierzenie mu w sposób niemal nieograniczony prowadzenia całej gospodarki finansowej jednostki. Nie budzi wątpliwości, że działanie takie w sposób jednoznaczny świadczy o niedochowaniu staranności, a także o niezachowaniu podstawowych reguł ostrożności i standardów postępowania adekwatnych do zajmowanego stanowiska. Działanie całkowicie lekkomyślne i zaniechanie czynności, które spoczywają na kierowniku j.s.f.p. w zakresie weryfikacji przedstawionej mu dokumentacji dotyczącej opłacania składek na ubezpieczenie społeczne, zostało krytycznie ocenione w orzeczeniu GKO z 29 października 2009 r..$^{30}$

Ponadto GKO w orzeczeniu z 5 marca 2009 r. $^{31}$, rozpatrując dochowanie należytej staranności przy prowadzeniu gospodarki finansowej j.s.f.p., wskazała, że sytuacja, w której trzeba dokonywać wyboru co do kolejności zaspokajania zobowiązań, ponieważ nie można ich terminowo regulować, stanowi wynik błędnej gospodarki finansowej, w tym przede wszystkim brak zharmonizowania pokrywanych kosztów i opłacanych zobowiązań z posiadanymi środkami i uzyskiwanymi przychodami. Rolą kierownika danej j.s.f.p. jest takie zorganizowanie płatności, aby zapew-

rialnego, Zeszyty Naukowe Uniwersytetu Szczecińskiego nr 802, Finanse, Rynki Finansowe, Ubezpieczenia nr 65, s. 41-43.

29 Por. orzeczenie GKO z 29 października 2009 r., BDF1/4900/52/52/09/1853, „Biuletyn Orzecznictwa NDFP” 2010, nr 1, s. 122; orzeczenie GKO z dnia 20 maja 2013 r., BDF1/4900/19/24/13/RWPD-13543, www.mf.gov.pl, dostęp: 24 czerwca 2014 r. oraz por.: R. Godoń, Odpowiedzialność kierownika jednostki za naruszenie dyscypliny finansów publicznych, [w:] T. Bojkowski, J. Przybylska (red.), Dyscyplina finansów publicznych. Zasady Odpowiedzialności, problemy orzecznicze i aspekty praktyczne, Warszawa 2012, s. 28-30.

30 Por. również cyt. orzeczenie GKO z dnia 27 września 2010 r.

31 Por.: Orzeczenie GKO z dnia 5 marca 2009 r., BDF1/4900/3/3/09/75, LexPolonica nr 2442811 oraz orzeczenie Regionalnej Komisji Orzekającej z dnia 31 marca 2006 r., KO/7101/87/05, „Biuletyn Orzecznictwa NDFP”2006, nr 3, poz. 2. 
nić ich terminowe regulowanie. Należyta staranność wymaga również wykorzystywania wszelkich dostępnych możliwości wykonania ciążących na jednostce zobowiązań publicznoprawnych, takich jak składki na ubezpieczenie społeczne. W analizowanym orzeczeniu wskazano, że kierownik j.s.f.p. powinien podejmować w stosunku do dłużników czynności zmierzające do wyegzekwowania od nich należności w celu pozyskania środków do terminowego regulowania zobowiązań i uniknięcia zapłaty odsetek, wykorzystując wszelkie przewidziane prawem sposoby. Co więcej, kierownik j.s.f.p. powinien wykorzystywać każdą możliwość opłacania zaległych zobowiązań, co przynajmniej w części przyczyniłoby się do zmniejszenia skali nieprawidłowości występujących w zarządzanej przez niego j.s.f.p. i destabilizujących ład w finansach publicznych.

W oparciu o treść art. 53 ust. 2 u.f.p. w związku z art. 4 pkt 3 u.o.n.d.f.p. istnieje możliwość powierzenia przez kierownika j.s.f.p. pracownikowi tej jednostki obowiązków w zakresie terminowego regulowania zobowiązań publicznoprawnych z art. 14 pkt 1 u.o.n.d.f.p. Nie oznacza to jednak całkowitego wyłączenia odpowiedzialności kierownika j.s.f.p., gdyż na podstawie art. 16 ust. 1 u.o.n.d.f.p. może być on pociągnięty do odpowiedzialności za niewykonanie w terminie zobowiązania j.s.f.p. (np. nienależnie opłaconych składek na ubezpieczenie społeczne lub zdrowotne, którego skutkiem jest zapłata odsetek, kar lub opłat albo oprocentowanie tych należności). Zatem w sytuacji naruszenia dyscypliny finansów publicznych opisanego w art. 14 pkt 1 u.o.n.d.f.p. przez pracownika danej jednostki, zawsze powinno się również rozważyć jednoczesną odpowiedzialność kierownika j.s.f.p. $\mathrm{z}$ art. 16 ust. 1 u.o.n.d.f.p. Należy jednak mieć na uwadze to, że tylko skuteczne powierzenie obowiązków podległemu pracownikowi, np. głównej księgowej, mogłoby zwolnić od odpowiedzialności za popełnienie zarzucanego czynu. Zgodnie z treścią ww. art. 4 pkt 3 u.o.n.d.f.p. odpowiedzialności za naruszenie dyscypliny finansów publicznych podlegają pracownicy sektora finansów publicznych, którym powierzono określone obowiązki w zakresie gospodarki finansowej ${ }^{32}$. Niezbędne jest jednak wykazanie $\mathrm{w}$ toku postępowania $\mathrm{w}$ sprawie o naruszenie dyscypliny

32 Szerzej: K. Puchacz, Odpowiedzialność kierownika jednostki sektora finansów publicznych a powierzenie obowiq̨zów pracownikom jednostki, Gdańsk 2012, s. 25-26. 
finansów publicznych, że kierownik j.s.f.p. powierzył określone obowiązki w zakresie gospodarki finansowej pracownikowi tej jednostki i uzyskał odpowiednie potwierdzenie $\mathrm{w}$ dokumencie $\mathrm{w}$ formie odrębnego imiennego upoważnienia albo wskazania $\mathrm{w}$ regulaminie organizacyjnym tej jednostki $^{33}$. W praktyce wielokrotnie zdarzają się sytuacje, że rzeczywiste sprawdzenie przez kierownika j.s.f.p. prawidłowości naliczonych składek na ubezpieczenie społeczne obiektywnie jest trudne, a czasami wręcz nawet niewykonalne. $\mathrm{W}$ takich okolicznościach kierownik j.s.f.p., mając świadomość ciążącej na nim odpowiedzialności (art. 53 ust. 1 u.f.p.), może skorzystać z możliwości powierzenia obowiązków w tym zakresie głównej księgowej albo innej osobie i tak postępować w przyszłości ${ }^{34}$. $\mathrm{Z}$ racji pełnionej funkcji kierownik j.s.f.p. powinien nie tylko znać zasady gospodarki finansowej i konsekwencje ich naruszenia, ale w razie wątpliwości interpretacyjnych powinien dokładnie przeanalizować sytuację i przepisy przed podjęciem decyzji, nie ograniczając się do dania wiary jakiejkolwiek opinii ${ }^{35}$. Tym samym nie można uznać za wystarczające powołanie się przez kierownika j.s.f.p. na otrzymane od głównego księgowego zapewnienie o dokonaniu wpłat w należytej wysokości, bez dokonania weryfikacji tych twierdzeń, gdyż samo działanie w zaufaniu do głównego księgowego j.s.f.p. nie wyłącza odpowiedzialności kierownika j.s.f.p. ${ }^{36}$

Niezbędnym elementem stwierdzenia naruszenia art. 14 pkt 1 u.o.n.d.f.p. jest przypisanie obwinionemu winy, co z kolei wiąże się z koniecznością wskazania, w jaki sposób sprawca czynu powinien był postąpić, aby jego zachowanie było legalne. Ma to o tyle istotne znaczenie, że w sytuacji, gdy sprawca czynu nie ma możliwości zachowania, które nie naruszałoby normy prawnej (np. dochowanie zasad dokonywania wydatków ze środków publicznych skutkowałoby naruszeniem obowiązku terminowego odprowadzania składek ubezpieczenia społecznego) nie można, co oczywiste, mówić o zachowaniu nienaruszającym żadnego

33 Por. orzeczenie GKO z dnia 21 maja 2009 r. DF1/4900/14/14/RN-2/09/534, „Biuletyn Orzecznictwa NDFP” 2009, nr 3, poz. 9.

34 Orzeczenie GKO z dnia 7 maja 2012 r., BDF1/4900/35/33-35/12/596, www.mf.gov.pl, dostęp: 24 czerwca $2014 \mathrm{r}$.

35 Zob. cyt. orzeczenie GKO z dnia 8 maja 2012 r.

36 Zob. cyt. wyrok NSA z dnia 12 czerwca 2003 r. 
przepisu. Dlatego w orzeczeniu GKO z 11 września 2008 r. ${ }^{37}$ wskazano, że zadaniem ustawodawcy jest ukształtowanie przepisów prawa w taki sposób, aby akty tej samej rangi nie pozostawały ze sobą w sprzeczności i jednocześnie były możliwe zachowania nienaruszające żadnego przepisu powszechnie obowiązującego. Zdaniem GKO od nikogo, w tym również od osoby odpowiedzialnej za dysponowanie środkami publicznymi, nie można wymagać, aby dokonywała oceny, który z przepisów rangi ustawowej jest „istotniejszy”, a który może zostać naruszony. Istotnym elementem odpowiedzialności za naruszenie dyscypliny finansów publicznych jest bezprawność czynu, a fakt, iż zachowanie skutkujące przekroczeniem uprawnień do dokonywania wydatków było jednocześnie realizacją obowiązku wynikającego z u.s.u.s., wyłącza bezprawność czynu, a tym samym wyłącza możliwość postawienia skutecznego zarzutu naruszenia dyscypliny finansów publicznych.

W perspektywie ostatnich pięciu pełnych lat budżetowych na gruncie finansów publicznych można zaobserwować relatywnie niewielką liczbę stwierdzanych naruszeń dyscypliny finansów publicznych z art. 14 u.o.n.d.f.p. ${ }^{38}$ Poniżej w formie wykresu zobrazowano częstotliwość popełniania ww. naruszeń i ich odniesienie do ogólnej liczby osób, którym przypisano w danym roku odpowiedzialność za naruszenie dyscypliny finansów publicznych.

Z wykresu wynika, że w 2009 r. udział procentowy naruszeń z art. 14 u.o.n.d.f.p. w ogólnej liczbie naruszeń wynosił 6,5\%, w 2010 r. - 4,4\%, w 2011 r. - 7\%, w 2012 r. - 4,1\%, zaś w 2013 r. - 4,5\%. Z pewnością uznać można, że penalizowane $\mathrm{w}$ art. 14 pkt 1 u.o.n.d.f.p. zachowanie godzi w podstawowe zasady, na których oparty jest polski system finansów publicznych, niemniej odnosząc liczbę naruszeń w ww. okresie do

37 Por.: orzeczenie GKO z dnia 11 września 2008 r., DF/GKO/4900/50/49/08/1982, „Biuletyn Orzecznictwa NDFP” 2009, nr 1, poz. 13.

38 W 2006 r. naruszenia dotyczące art. 14 u.o.n.d.f.p. w jej ówczesnym brzmieniu stanowiły najczęstsze naruszenie dyscypliny finansów publicznych, tj. ok. $28 \%$ wszystkich naruszeń. Szerzej: L. Lipiec-Warzecha, Egzekwowanie odpowiedzialności za naruszenie dyscypliny finansów publicznych. Wybrane problemy, „Finanse Komunalne” 2007, nr 9, s. 5-6. 
stanu z 2008 r. (401/6876 naruszeń) z 2007 r. (566/6062 naruszenia) oraz z 2006 r. (1149/4053 naruszenia), zauważalny jest znaczny ich spadek ${ }^{39}$.

Wykres 1. Naruszenia art. 14 u.o.n.d.f.p. w latach 2009-2013 na tle ogólnej liczby naruszeń dyscypliny finansów publicznych w danym roku.

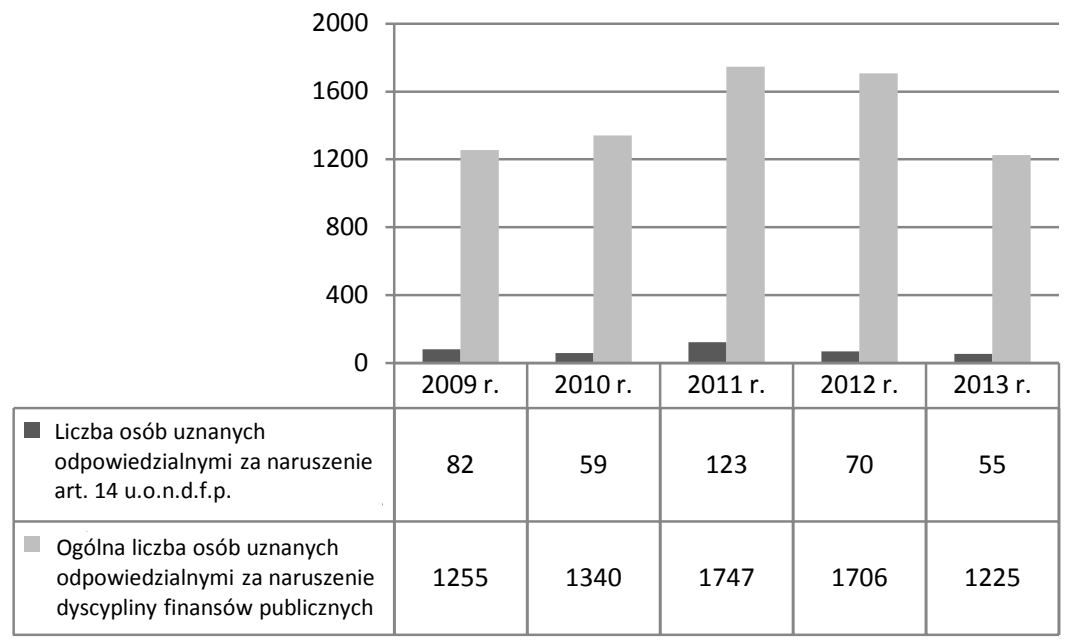

Źródło: Sprawozdania z działalności Głównej Komisji Orzekającej w Sprawach o Naruszenie Dyscypliny Finansów Publicznych oraz zbiorcze sprawozdania z działalności komisji orzekających I instancji w latach 2009-2013, www.mf.gov.pl, dostęp: 24 czerwca $2014 \mathrm{r}$.

\section{Negatywne przesłanki odpowiedzialności za naruszenie dyscypliny finansów publicznych o którym mowa w art. 14 pkt 1 u.o.n.d.f.p.}

Fundamentalna zasada odpowiedzialności za naruszenie dyscypliny finansów publicznych wyrażona w art. 19 u.o.n.d.f.p. zakłada, że odpowiedzialność taką ponosi osoba, która popełniła czyn naruszający dyscyplinę

39 Sprawozdania z działalności Głównej Komisji Orzekającej w Sprawach o Naruszenie Dyscypliny Finansów Publicznych oraz zbiorcze sprawozdania z działalności komisji orzekających I instancji w latach 2006-2008, www.mf.gov.pl, dostęp: 24 czerwca 2014 r. 
finansów publicznych określony przez ustawę obowiązującą w czasie jego popełnienia, a nadto której można przypisać winę w czasie popełnienia naruszenia. Konieczne staje się zatem wskazanie takiego sposobu zachowania się obwinionej osoby, które pozwoliłoby - mając na uwadze art. 14 ust. 1 u.o.n.d.f.p. - na regulowanie płatności terminowo i w odpowiedniej wysokości. Jeżeli bowiem osoba obwiniona nie miała innej możliwości zachowania się, to pomimo obiektywnego stwierdzenia popełnienia czynu zabronionego, nie będzie można przypisać jej winy ${ }^{40}$.

Wśród okoliczności ekskulpujących odpowiedzialność za naruszenie dyscypliny finansów publicznych, o którym mowa w art. 14 pkt 1 u.o.n.d.f.p., tj. przesłanek wyłączających ponoszenie tej odpowiedzialności, w pierwszej kolejności wskazać można na usprawiedliwioną nieświadomość naruszenia dyscypliny finansów publicznych (art. 23 u.o.n.d.f.p.). Niemniej jednak należy pamiętać, że dla wyłączenia odpowiedzialności nie jest wystarczające uznanie się przez samego obwinionego za nieświadomego swoich zadań i obowiązków, powołanie się na brak znajomości prawa czy też na brak doświadczenia ze względu na krótki okres zatrudnienia $^{41}$. Zgodnie bowiem z orzecznictwem $\mathrm{GKO}^{42}$ : „Dyscyplina finansów publicznych obowiązuje bowiem osoby, które pełniąc funkcje kierowników jednostek organizacyjnych odpowiadają za całość ich gospodarki finansowej w sposób świadomy. Osoby nieświadome swoich obowiązków oraz obowiązków kierowanej jednostki organizacyjnej nie powinny takich stanowisk zajmować, ponieważ stanowi to samo przez się zagrożenie dla dyscypliny finansów publicznych”. Zdarzyć się oczywiście mogą również sytuacje, w których nieznajomość przepisów prawa może stanowić usprawiedliwienie nieświadomości, lecz konieczne jest wykazanie tego, że brak wiedzy wynika z przyczyn obiektywnych, np. gdy sprawca nie mógł zapoznać się z treścią aktu prawnego ze względu na krótki okres vacatio legis czy opóźnienia w kolportażu dziennika, w którym został

40 Por. odpowiednio orzeczenie GKO z dnia 14 czerwca 2012 r., BDF1/4900/49/ 48/12/1338 oraz Orzeczenie GKO z dnia 21 kwietnia 2013 r., BDF1/4900/14/18/RN7/13/RWPD-1393, www.mf.gov.pl, dostęp: 24 czerwca 2014 r.

41 Por. Orzeczenie GKO z dnia 21 kwietnia 2013 r.

42 Orzeczenie GKO z dnia 2 marca 2009 r., BDF1/4900/111/100/08/1189, Lexis.pl nr 432221. 
opublikowany ${ }^{43}$, a nadto braku możliwości pozyskania środków na opłacenie świadczeń na ubezpieczenie społeczne (ze względu na brak zdolności kredytowej i wolnych środków) w dniu lub nieznacznie po objęciu stanowiska przez kierownika j.s.f.p. ${ }^{44}$

Ponadto ustawodawca wskazuje, że nie dochodzi się odpowiedzialności za naruszenie dyscypliny finansów publicznych w przypadku działania lub zaniechania podjętego wyłącznie w celu ograniczenia skutków zdarzenia losowego (art. 27 ust. 1 u.o.n.d.f.p.). Zachowanie, o którym mowa wyżej, usprawiedliwia każde wymienione w ustawowym katalogu naruszenie dyscypliny finansów publicznych, zatem również z art. 14 pkt 1 u.o.n.d.f.p. Trzeba jednak ww. okoliczność traktować w ścisłym związ$\mathrm{ku} \mathrm{z}$ definicją legalną zdarzenia losowego zawartą w art. 27 ust. 2 u.o.n.d.f.p. Sformułowana na gruncie u.o.n.d.f.p. legalna definicja zdarzenia losowego stanowi, że jest nim zdarzenie wywołane przez czynniki zewnętrzne, którego nie można przewidzieć z pewnością, w szczególności zagrażające bezpośrednio życiu lub zdrowiu ludzi lub grożące powstaniem szkody niewspółmiernie większej niż spowodowana działaniem lub zaniechaniem naruszającym dyscyplinę finansów publicznych. Mając powyższe na uwadze, GKO w orzeczeniu z 4 listopada $2010 \mathrm{r} .{ }^{45}$ wskazała, że szczególnie trudna sytuacja finansowa szpitala spowodowana strajkiem lekarzy nie może stanowić podstawy umorzenia postępowania. Obwiniony $w$ toku ww. postępowania twierdził, że strajk personelu medycznego był zdarzeniem losowym, jednak w ocenie GKO nie można było przyjąć, że nieterminowe regulowanie zobowiązań wobec kontrahentów i niedokonywanie w terminach wpłat należnych składek było działaniem podjętym w celu ograniczenia jego skutków. Wykonywanie zadań publicznych przez j.s.f.p., nawet $\mathrm{w}$ zwiększonym wymiarze, nie mogło przesądzać o zapobieżeniu szkodzie w mieniu publicznym, usunięciu takiej szkody,

43 M. Drążkiewicz, Dyscyplina Finansów Publicznych, „Poradnik Rachunkowości Budżetowej" 2007, nr 2, s. 14.

44 Por. orzeczenie GKO z dnia 20 stycznia 2003 r., DF/GKO/Odw.-120/156/RN-34/2002, cyt. za: L. Lipiec-Warzecha, Odpowiedzialność..., s. 175.

45 Orzeczenie GKO z dnia 4 listopada 2010 r., BDF1/4900/79/90/10/2216, „Biuletyn Orzecznictwa NDFP” 2011, nr 1, poz. 11. 
czy też ograniczeniu społecznych skutków zdarzenia losowego ${ }^{46}$. Podobnie zaplanowanie zbyt małych środków dla j.s.f.p. nie jest zdarzeniem losowym, co stanowiło przedmiot rozważań Naczelnego Sądu Administracyjnego w wyroku z 12 czerwca 2013 r. ${ }^{47}$

Okolicznością, która może mieć wpływ na wynik postępowania w sprawie o czyn z art. 14 pkt 1 u.o.n.d.f.p., jest również znikomy stopień szkodliwości czynu dla finansów publicznych, przy ocenie którego uwzględnia się m.in. wagę naruszonych obowiązków, sposób i okoliczności ich naruszenia, skutki naruszenia (art. 28 ust. 1 i 2 u.o.n.d.f.p.) ${ }^{48}$. Warto przy tym zwrócić uwagę na to, że ustawodawca nie określił wartościowych granic (limitów kwotowych) skutków naruszenia dyscypliny finansów publicznych, które umożliwiałyby dokonanie oceny, czy dane naruszenie spowodowało znikomą szkodę dla finansów publicznych. Konieczne w tym miejscu jest podkreślenie, że stopnia szkodliwości dla finansów publicznych nie można oceniać wyłącznie w kontekście uszczerbku w mieniu publicznym bądź strat finansowych poniesionych przez j.s.f.p. ${ }^{49}$. Świadczy o tym fakt, że katalog możliwych naruszeń dyscypliny finansów publicznych zawiera wiele czynów, z popełnieniem których nie wiążą się żadne skutki finansowe ${ }^{50}$.

GKO wskazała, iż pomimo tego, że naruszenie z art. 14 pkt 1 u.o.n.d.f.p. nie powoduje uszczerbku w finansach publicznych, polegającego na ich uszczupleniu, nieprawidłowości te charakteryzuje znaczna szkodliwość dla ładu finansów publicznych w sytuacji, gdy nieterminowe przekazywanie należności ustawowych obciążających jednostkę trwa

46 Orzeczenie GKO z dnia 13 maja 2002 r., DF/GKO/Odw.-30/38/2002, cyt. za: L. Lipiec-Warzecha, Ustawa o finansach publicznych. Komentarz, Warszawa 2011, s. 220.

47 Wyrok NSA z dnia 12 czerwca 2003 r., III SA 305/2001, LexPolonica nr 402618.

48 Szerzej: J.M. Salachna, R. Trykozko, $W$ jakich przypadkach popełnienie czynu określonego w ustawie o odpowiedzialności za naruszenie dyscypliny finansów publicznych nie będzie wywoływać odpowiedzialności?, [w:] C. Kosikowski, J.M. Salachna (red.), Finanse samorzqdowe. 580 pytań i odpowiedzi, Warszawa 2012, s. 823-824.

49 Por. art. 28 ust. 3 i 4 u.o.n.d.f.p.

50 Por.: orzeczenie GKO z dnia 15 marca 2007 r., DF/GKO-4900-97/117/06/3334, „Biuletyn Orzecznictwa NDFP” 2007, nr 3, poz. 5 oraz I. Motowilczuk, Naruszenie dyscypliny finansów publicznych w praktyce, „Poradnik Rachunkowości Budżetowej” 2010, nr 2, s. 65-66. 
kilka miesięcy ${ }^{51}$ czy lat $^{52}$. Zaniedbań tego rodzaju nie mogą usprawiedliwiać ani przejściowe trudności finansowe j.s.f.p., ani sporządzenie przez kierownika tej jednostki programu naprawy finansów jednostki samorządu terytorialnego. Zapłata składek jest wydatkiem przewidywalnym, planowanym i cyklicznym, a co najważniejsze obowiązkiem ustawowym, dlatego niedopuszczalne jest przyjęcie niezgodnej z przepisami prawa polityki zarządzania finansami jednostki i jej konsekwentne realizowanie przez dłuższy czas. Wydatek ten należy przewidywać już na etapie tworzenia planu finansowego j.s.f.p., a obowiązkiem planującego jest zabezpieczenie odpowiednich środków na ten cel nawet kosztem niezaciągania żadnych innych zobowiązań. Reasumując, jeśli odprowadzenie składek na ubezpieczenie społeczne z przekroczeniem terminu ich zapłaty miało charakter wielokrotny lub też długotrwały, to należy stwierdzić, że taki stan rzeczy jest nie do zaakceptowania i nie może korzystać z dobrodziejstwa art. 28 u.o.n.d.f.p. ${ }^{53}$

Nie poniesie również odpowiedzialności osoba, która naruszyła dyscyplinę finansów publicznych wskutek wykonania polecenia przełożonego albo kierownika jednostki, dysponenta środków publicznych, organu nadzorującego lub organu założycielskiego (art. 29 u.o.n.d.f.p.). Przy czym istotne jest zgłoszenie przez ww. osobę - przed wykonaniem polecenia - pisemnego zastrzeżenia i, pomimo tego zastrzeżenia, otrzymanie pisemnego potwierdzenie wykonania polecenia albo brak odwołania lub zmiany tego polecenia. W określonym wyżej przypadku odpowiedzialność poniesie osoba, która podpisała się pod pisemnym poleceniem wykonania polecenia, a przy braku takiego dokumentu - osoba, która wydała takie polecenie ${ }^{54}$. Zasada ta odnosi się odpowiednio do osoby wykonują-

51 Orzeczenie GKO z dnia 29 marca 2012 r., BDF1/4900/29/27/12/545, LexPolonica nr 3874738.

52 Zob. cyt. orzeczenie GKO z dnia 14 stycznia 2013 r.

53 Por. cyt. orzeczenie GKO z dnia 27 września 2010 r.

54 Szerzej: M. Czyżak, Działanie na polecenie przełożonego jako okoliczność uchylajqca odpowiedzialność za naruszenie dyscypliny finansów publicznych, „Finanse Komunalne” 2011, nr 6, s. 13-14. 
cej uchwałę organu, o którym mowa w art. 4 ust. 1 pkt 1 u.o.n.d.f.p., i członków organów kolegialnych ${ }^{55}$.

Uzupełnienie ww. katalogu okoliczności wyłączających odpowiedzialność za naruszenie dyscypliny finansów publicznych stanowi również zbieg postępowania w sprawie o naruszenie dyscypliny finansów publicznych $\mathrm{z}$ postępowaniem $\mathrm{w}$ sprawie o przestępstwo, przestępstwo skarbowe, wykroczenie, wykroczenie skarbowe (art. 25 ust. 2 i 3 u.o.n.d.f.p.), upływ terminu przedawnienia (art. 38 ust. 1 u.o.n.d.f.p.), ustanie karalności (art. 38 ust. 2 u.o.n.d.f.p.), niemożność wykonania kary (art. 39 u.o.n.d.f.p.) ${ }^{56}$.

W celu kompleksowego rozważenia wszystkich istotnych z punktu widzenia analizowanego zagadnienia kwestii, warto również wskazać kilka okoliczności, często podnoszonych w toku postępowania przed GKO, które nie wyłączają odpowiedzialności za naruszenie dyscypliny finansów publicznych z art. 14 pkt 1 u.o.n.d.f.p. Okolicznością ekskulpujące ww. odpowiedzialność nie jest - co do zasady - trudna sytuacja finansowa j.s.f.p. ${ }^{57}$, choć brak środków na rachunku bankowym może wyłączać winę kierownika jednostki budżetowej, który pozostaje bez wpływu na działania podejmowane przez dysponenta wyższego szczebla i ustalony przez niego termin oraz wysokość przekazywanych środków ${ }^{58}$. Dalej zaś, nie wyłączają odpowiedzialności: „zlecanie dodatkowych zadań przez władze wyższego szczebla, praktyka stosowana w j.s.f.p. przed dniem wejścia w życie ustawy o finansach publicznych czy wreszcie błędy formalno-proceduralne popełnione przez prowadzących rewizję finansowo-gospodarczą, w czasie której stwierdzono przekroczenie dyscypliny finansów publicznych (...)”59, brak zapłaty odsetek przez j.s.f.p. czy zapła-

55 Por. orzeczenie GKO z dnia 12 października 2006 r., DF/GKO-4900-64/81/06/1944, „Biuletyn Orzecznictwa NDFP” 2007, nr 1, poz. 11 oraz T. Strąk, Zmiany w orzekaniu o odpowiedzialności kierownika, „Kadra Kierownicza w Administracji”, 2012, nr 3, s. 33. Szerzej: Z. Ofiarski, Prawo finansowe, Warszawa 2010, s. 446.

57 K. Borowska zauważa, że niezawiniony przez kierownika jednostki brak środków finansowych na jej koncie może - w pewnych sytuacjach - stanowić okoliczność ekskulpującą od odpowiedzialności za naruszenie dyscypliny finansów publicznych. Por. K. Borowska, Komentarz do art. 14 u.o.n.d.f.p. ..., s. 93-94.

58 Por. L. Lipiec-Warzecha, Odpowiedzialność..., s. 176.

59 Zob. cyt. orzeczenie GKO z dnia 4 listopada $2010 \mathrm{r}$. 
ta odsetek przez pracownika tej jednostki, bezpośrednio odpowiedzialnego za zaistniałe naruszenie ${ }^{60}$. Co więcej, w orzeczeniu GKO z 5 marca 2009 r. ${ }^{61}$ wskazano, że sytuacja, w której trzeba dokonywać wyboru co do kolejności zaspokajania zobowiązań, ponieważ nie można ich terminowo regulować, jest wynikiem błędnej gospodarki finansowej, a zwłaszcza braku zharmonizowania pokrywanych kosztów i opłacanych zobowiązań z posiadanymi środkami i uzyskiwanymi przychodami. Dlatego wydatkowanie środków na inne cele, nawet i pragmatycznie uzasadnione, z pominięciem płatności zobowiązań obligatoryjnych i ustawowo obwarowanych odsetkami za opóźnienie w zapłacie, nie może być wystarczającym usprawiedliwieniem braku środków w terminach ich płatności. Także wydanie posiadanych środków na inny cel na krótko przed terminem płatności obligatoryjnych i ustawowo obwarowanych odsetkami za opóźnienie w zapłacie świadczeń nie może być usprawiedliwieniem braku środków w ostatnim dniu terminu płatności ${ }^{62}$.

\section{Zakończenie}

W orzecznictwie i doktrynie - bez względu na wielokrotnie słuszne intencje obwinionego - jednoznacznie krytycznie ocenia się zachowania naruszające zasadę bezwzględnego pierwszeństwa terminowej realizacji zobowiązań ustawowych i destabilizujące ład finansów publicznych. Dokonując wydatków w j.s.f.p., niedopuszczalne jest indywidualne, sprzeczne

60 Por. orzeczenie GKO z dnia 13 października 2011 r., BDF1/4900/86/93/11/2654, Lexis.pl nr 3027574, ale por. również orzeczenie z dnia 13 października 2011 r., BDF1/4900/86/93/11/2654, Lexis.pl nr 3027574, w którym o znikomym stopniu szkodliwości czynu dla finansów publicznych decydowało m.in. pokrycie odsetek za zwłokę oraz opłacenie przelewu przez pracownika bezpośrednio odpowiedzialnego za uchybienie terminowi płatności.

61 Orzeczenie GKO z dnia 5 marca 2009 r., BDF1/4900/3/3/09/75, LexPolonica nr 2442811, podobnie w cyt. orzeczeniu GKO z dnia 27 września 2010 r.

62 Orzeczenie GKO z dnia 26 października 2006 r., DF/GKO-4900-75/93/06/2254, „Biuletyn Orzecznictwa NDFP” 2007, nr 1, poz. 15. 
z obowiązującym porządkiem prawnym ustalanie hierarchii ważności w zakresie kolejności realizacji zobowiązań publicznoprawnych ${ }^{63}$.

Analizując liczbę popełnionych naruszeń z art. 14 u.o.n.d.f.p., można sformułować wniosek, że w porównaniu do lat 2006-2008 w okresie ostatnich pięciu lat ma miejsce znacznie mniejsza częstotliwość ich popełniania.

Z kolei dokonując przeglądu orzecznictwa GKO oraz komisji orzekających w sprawach o naruszenie dyscypliny finansów publicznych w pierwszej instancji, należy zwrócić uwagę na to, że o wyłączeniu tej odpowiedzialności przede wszystkim decyduje znikomy stopień szkodliwości dla finansów publicznych (przy czym wielokrotnie duże znaczenie ma tu czas opóźnienia w opłaceniu składek na ubezpieczenie społeczne). Pozostałe okoliczności ekskulpujące odpowiedzialność za naruszenie dyscypliny finansów publicznych z art. 14 pkt 1 u.o.n.d.f.p. (nieświadomość, zdarzenie losowe itp.) pojawiają się rzadko, zaś ich podnoszenie na poszczególnych etapach postępowań jest przeważnie nieskuteczne, gdyż stanowią one jedynie linię obrony przyjętą przez obwinionych, opartą o subiektywną i racjonalnie oraz prawnie nieuzasadnioną argumentację.

W większości analizowanych orzeczeń odpowiedzialność za czyn z art. 14 pkt 1 u.o.n.d.f.p. dotyczyła kierowników j.s.f.p., co wynikało m.in. z braku podstawowej wiedzy dotyczącej zasad gospodarki finansowej i obowiązującego porządku prawnego, niezachowania należytej staranności w prowadzeniu gospodarki finansowej jednostki, przejawiającym się nadmiernym zaufaniem do podległych pracowników i niepodejmowaniem czynności kontrolnych umożliwiających weryfikację dokumentacji j.s.f.p. Nierzadkie były również przypadki powoływania się na trudną sytuację finansową jednostki czy inne wyjątkowe okoliczności.

Piętnowanie zachowań polegających na nieopłacaniu w terminie lub na opłacaniu w nienależytej wysokości składek na ubezpieczenie społeczne jest w pełni zasadne, zaś konsekwencja i jednolitość kierunków orze-

63 Por.: orzeczenie Regionalnej Komisji Orzekającej w Sprawach o Naruszenie Dyscypliny Finansów Publicznych przy Regionalnej Izbie Obrachunkowej w Warszawie z 31 maja 2010 r., RIO-IV-R-19/09-K-83/09, [w:] Dyscyplina finansów publicznych stan obecny i kierunki zmian, M. Smaga, M. Winiarz (red.) Kraków 2011, s. 322, czy też cyt. orzeczenie GKO z dnia 5 marca 2009 r. 
kania w takich sprawach wskazuje na to, że wykładnia przepisu art. 14 pkt 1 u.o.n.d.f.p. w coraz mniejszym stopniu powinna budzić wątpliwości.

\section{Bibliografia:}

Borowska K., Komentarz do art. 14 u.o.n.d.f.p., [w:] K. Borowska, A. Kościńska-Paszkowska, T. Bolek, Odpowiedzialność za naruszenie dyscypliny finansów publicznych. Komentarz, LexisNexis, Warszawa 2012.

Bożek W., Niewykonanie lub nienależyte wykonanie przez kierownika jednostki sektora finansów publicznych obowiq̨zków w zakresie kontroli zarzq̨dczej w jednostce sektora finansów publicznych, [w:] D. Zarzecki (red.), Zarzqdzanie Finansami. Zarzq̨dzanie finansami w przedsiębiorstwach i jednostkach samorzqdu terytorialnego, Zeszyty Naukowe Uniwersytetu Szczecińskiego nr 802, Finanse, Rynki Finansowe, Ubezpieczenia nr 65.

Cholewa-Klimek M., Postępowanie sq̨dowe w sprawach z zakresu ubezpieczeń społecznych, Warszawa 2010.

Czyżak M., Działanie na polecenie przełożonego jako okoliczność uchylajq̨ca odpowiedzialność za naruszenie dyscypliny finansów publicznych, „Finanse Komunalne” 2011, nr 6, s. 11-19.

Drążkiewicz M., Dyscyplina finansów publicznych, „Poradnik Rachunkowości Budżetowej” 2007, nr 2, s. 14.

Dziedzic A., Naruszenia z art. 14 i 15 ustawy, „Kontrola Finansowa” 2012, nr 9, s. 26-31.

Godoń R., Odpowiedzialność kierownika jednostki za naruszenie dyscypliny finansów publicznych, [w:] T. Bojkowski, J. Przybylska (red.), Dyscyplina finansów publicznych. Zasady Odpowiedzialności, problemy orzecznicze i aspekty praktyczne, CeDeWu, Warszawa 2012.

Kowalczyk E., Odpowiedzialność kierownika i głównego księgowego jednostki sektora finansów publicznych w zakresie rachunkowości i gospodarki finansowej, ODDK, Gdańsk 2012.

Lipiec-Warzecha L., Egzekwowanie odpowiedzialności za naruszenie dyscypliny finansów publicznych. Wybrane problemy, „Finanse Komunalne” 2007, nr 9, s. 5-12.

Lipiec-Warzecha L., Odpowiedzialność za naruszenie dyscypliny finansów publicznych. Komentarz, Wolters Kluwer, Warszawa 2012.

Lipiec-Warzecha L., Ustawa o finansach publicznych. Komentarz, Wolters Kluwer, Warszawa 2011. 
Motowilczuk I., Naruszenie dyscypliny finansów publicznych w praktyce, „Poradnik Rachunkowości Budżetowej” 2010, nr 2, s. 65-66.

Ofiarski Z., Komentarz do art. 46 u.f.p., [w:] M. Karlikowska, W. Miemiec, Z. Ofiarski, K. Sawicka, Ustawa o finansach publicznych. Komentarz, Wydawnictwo Presscom Sp. z o.o., Wrocław 2010.

Ofiarski Z., Prawo finansowe, C.H. Beck, Warszawa 2010.

Puchacz K., Odpowiedzialność kierownika jednostki sektora finansów publicznych a powierzenie obowiqzzów pracownikom jednostki, ODDK, Gdańsk 2012.

Salachna J.M., Trykozko R., W jakich przypadkach popełnienie czynu określonego w ustawie o odpowiedzialności za naruszenie dyscypliny finansów publicznych nie będzie wywoływać odpowiedzialności?, [w:] C. Kosikowski, K.M. Salachna (red), Finanse samorzq̨dowe. 580 pytań i odpowiedzi, Wolters Kluwer, Warszawa 2012.

Smaga M., Winiarz M., Dyscyplina finansów publicznych. Narzędzie prawidłowej gospodarki sektora publicznego, Kraków 2013.

Strąk T., Zmiany w orzekaniu o odpowiedzialności kierownika, „Kadra Kierownicza w Administracji”, 2012, nr 3, s. 32-34.

Szyburska-Walczak G., Ubezpieczenia Społeczne, Wolters Kluwer, Warszawa 2012.

Sprawozdania z działalności Głównej Komisji Orzekającej w Sprawach o Naruszenie Dyscypliny Finansów Publicznych oraz zbiorcze sprawozdania z działalności komisji orzekających I instancji w latach 2006-2013, www.mf.gov.pl, dostęp: 24 czerwca 2014 r. 